\title{
Bioedusiana
}

http://jurnal.unsil.ac.id/index.php/bioed

DOI: https://doi.org/10.37058/bioed.v5i2.1995

Bioedusiana

\section{KESULITAN BELAJAR MAHASISWA PADA MATA KULIAH BIOKIMIA}

\section{Student Learning Difficulties in Biochemistry}

\author{
Zenia Lutfi Kurniawati ${ }^{1 *}$, Jailani ${ }^{2}$ \\ 1,2 Program Studi Pendidikan Biologi FKIP Universitas Mulawarman, J1. Muara Pahu, Samarinda, \\ Indonesia, 75123
}

\begin{abstract}
Abstrak
Biokimia mempelajari tentang komposisi kimia, struktur penyusun substansi dan transformasinya pada tubuh makhluk hidup. Materi biokimia cenderung abstrak dan sulit untuk dipelajari. Kesulitan ini diindikasikan dengan hasil belajar mahasiswa yang rendah pada mata kuliah biokimia. Tujuan penelitian ini adalah untuk mengungkapkan kesulitan-kesulitan belajar mahasiswa serta untuk membantu mahasiswa menemukan solusi dalam proses belajar mata kuliah biokimia. Penelitian ini merupakan penelitian deskriptif dengan metode survei. Data dikumpulkan menggunakan instrumen berupa kuesioner. Subjek penelitian ini adalah mahasiswa Pendidikan Biologi FKIP Unmul dengan partisipan sejumlah 38 orang mahasiswa yang menempuh MK Biokimia dengan teknik pengambilan sampel menggunakan purposive sampling. Data dianalisis secara kualitatif menggunakan teknik persentase. Hasil penelitian menunjukkan bahwa kesulitan belajar mahasiswa terkait dengan materi biokimia, yaitu tentang struktur molekul, jalur metabolisme dan istilah-istilah dalam biokimia, secara umum cara belajar biokimia yang disenangi oleh mahasiswa ialah melalui penjelasan dosen dan kegiatan diskusi, sumber belajar yang digunakan oleh mahasiswa dalam mempelajari materi biokimia secara umum ialah menggunakan data dari internet, penjelasan dosen dan buku biokimia. Upaya yang dapat dilakukan untuk membantu mengatasi kesulitan belajar mahasiswa ialah dengan mengembangkan berbagai bahan ajar yang dapat membantu mahasiswa untuk belajar misalnya dengan menggunakan video pembelajaran, buku ajar, modul, petunjuk praktikum serta bahan tayang yang menarik dan mudah dipahami
\end{abstract}

Kata kunci: Kesulitan belajar; Pembelajaran; Biokimia

\begin{abstract}
Biochemistry studies the chemical composition, structure of substances and their transformations in the bodies of living things. Biochemical material tends to be abstract and difficult to study. This difficulty is indicated by the low student learning outcomes in biochemistry courses. The purpose of this study was to reveal student learning difficulties and to help students find solutions in the learning process of biochemistry courses. This research is a descriptive study with a survey method. Data were collected using an instrument in the form of a questionnaire. This research's subject is 38 students of Biology Department, Teacher training \& Education Faculty, Mulawarman University that take biochemistry course. Sample was collected using purposive sampling. The data were analyzed qualitatively using the percentage technique. The results showed that students 'learning difficulties were related to biochemical material, namely about molecular structure, metabolic pathways and terms in biochemistry, in general the way to learn biochemistry that students liked was through lecturers' explanations and discussion activities, learning resources used by students in studying biochemistry material in general is using data from the internet, lecturers' explanations and biochemistry books. Efforts that can be made to help students overcome learning difficulties are to develop various teaching materials that can help students learn, for example by using instructional videos, textbooks, modules, practicum instructions and presentations as well as broadcast material that is interesting and easy to understand .
\end{abstract}

Keywords: Student Learning Difficulties; Learning; Biochemistry

\section{Article History}

Received: August, $18^{\text {th }}$ 2020; Accepted: November, $17^{\text {th }} 2020$; Published: December, $31^{\text {st }} 2020$

Corresponding Author*

Zenia Lufti Kurniawati, Program Studi Pendidikan Biologi, FKIP, Universitas Mulawarman, Samarinda E-mail: zeniakurniawati2211@gmail.com 


\section{PENDAHULUAN}

Biokimia merupakan sains yang mempelajari tentang komposisi kimia dari makhluk hidup, struktur penyusun substansinya dan transformasinya di dalam tubuh makhluk hidup atau yang biasa dikenal dengan metabolisme (Butnariu et al., 2018). Materi biokimia pada umumnya mencakup tentang pengantar biokimia, biomolekul, enzim, metabolisme, ekspresi gen dan replikasi (Voet, Voet, \& Pratt, 2016). Rodwell et al., (2018) membahas materi biokimia ke dalam beberapa bahasan, diantaranya 1) struktur dan fungsi protein dan enzim, 2) kinetika, mekanisme, regulasi, dan peranan transisi metal enzim, 3) bioenergetika, 4) metabolisme karbohidrat, lipid, protein dan asam amino, 5) struktur, fungsi dan replikasi makromolekul, 6) biokimia komunikasi ekstraseluler dan intraseluler. Dibahas pula tentang analisis tentang komposisi kimia pada tubuh, kompleksitas perubahan substansi pada makhluk hidup, dan menginvestigasi proses-proses kimia vital (Butnariu, Petrescu, \& Ioan, 2018). Perumcheril (2017) menjelaskan bahwa biokimia membahas tentang asam amino dan protein, karbohidrat, lemak, genetika molekuler, metabolisme heme dan hemoglobin, oksidasi biologis dan siklus krebs. Pada pembahasan yang lebih ringkas, biokimia membahas asam amino dan protein, lipid, karbohidrat dan asam nukleat (ŻymańczykDuda et al., 2016)

Beberapa sekolah dan perguruan tinggi juga memasukkan biokimia sebagai mata kuliahnya. Salah satu standar kompetensi pada mata kuliah biokimia diantaranya agar mahasiswa memiliki pengetahuan yang berkaitan dengan reaksi biokimia yang terjadi pada metabolisme tubuh serta mampu mengembangkan aplikasinya dalam kehidupan sehari hari dengan materi yang mencakup metabolisme karbohidrat, protein, lipid, vitamin, mineral dan lain sebagainya (Wijayanti \& Lestari, 2016). Kajian biokimia pada dapat pula mencakup tentang susunan kimia sel, sifat senyawa reaksi kimia yang terjadi di sel, dan penerapan prinsip-prinsip kimia dalam memahami biologi (Wahyuni, 2019). Setiap sumber belajar baik berupa textbook, diktat, maupun artikel tentang biokimia memiliki tata urutan materi yang berbeda satu sama lain tetapi memiliki unsur komponen utama materi biokimia, yaitu struktur dan fungsi biomolekuler dan jalur metabolisme. Mata kuliah biokimia pada Program Studi Pendidikan Biologi FKIP Universitas Mulawarman merupakan mata kuliah yang memuat tentang struktur dan fungsi sel, karbohidrat, protein, lemak, asam nukleat, enzimologi, oksidasi biologis dan energi biokimia, proses anabolisme dan katabolisme karbohidrat, lemak, protein. Dapat dikatakan bahwa mata kuliah biokimia membekali mahasiswa untuk dapat memahami materi struktur tubuh makhluk hidup dan fisiologi makhluk hidup. Oleh karenanya biokimia merupakan salah satu mata kuliah interdisiplin yang penting untuk dipelajarkan kepada mahasiswa calon guru IPA, biologi, dan kimia. 
Perkuliahan biokimia telah dilaksanakan berbasis mahasiswa aktif. Pembelajaran tatap muka di kelas juga diikuti oleh mahasiswa dengan antusias dan bersungguh-sungguh. Pembelajaran juga dibantu dengan kegiatan praktikum serta memanfaatkan teknologi informasi sebagaimana harusnya pembelajaran berlangsung pada era revolusi industri 4.0. Pembelajaran yang telah diupayakan sedemikian rupa nampaknya belum dapat memberikan hasil yang baik dilihat dari hasil belajar mahasiswa baik melalui kuis dan ujian tengah semester, ujian praktikum, dan ujian akhir semester pada mahasiswa yang menempuh mata kuliah biokimia pada tahun akademik 2019/2020. Hasil belajar yang rendah merupakan salah satu indikasi adanya kesulitan belajar. (Rizki, Nugraha, Saleh, 2017). Wahyuni (2019) menguatkan bahwa mahasiswa yang mengalami kesulitan belajar dibuktikan dari hasil ujian sumatif yang rendah.

Kesenjangan yang terjadi antara upaya yang telah dilakukan dalam proses pembelajaran dengan hasil belajar mahasiswa pada mata kuliah biokimia mendorong dilakukannya pengkajian lebih lanjut terhadap permasalahan yang terjadi. Permasalahan yang terjadi dengan mahasiswa yang mengambil mata kuliah biokimia dapat digolongkan sebagai kesulitan belajar. Kesulitan belajar adalah suatu kondisi dalam pembelajaran yang ditandai dengan hambatan-hambatan tertentu untuk mencapai hasil belajar (Cahyono, 2019). Kesulitan belajar dapat pula diartikan sebagai gangguan psikologis seorang pembelajar yang memiliki fisik sempurna tetapi sulit menerima ataupun menangkap pembelajaran dengan baik (Utami, 2019). Kesulitan belajar dapat dipelajari lebih lanjut melalui kegiatan diagnosis kesulitan belajar. Diagnosis kesulitan belajar adalah segala upaya yang dilakukan untuk menemukan kesulitan belajar, menetapkan jenis-jenis kesulitan belajar yang dialami, sifat-sifat kesulitan belajar, mempelajari tentang faktor penyebab kesulitan belajar serta mengetahui cara-cara untuk mencegah dan mengatasi kesulitan belajar (Ismail, 2016). Diagnosis kesulitan belajar mahasiswa dapat dilakukan dengan melakukan tes diagnostik secara tes maupun non tes, yaitu melalui wawancara, observasi dan lain sebagainya.

Diagnosis terhadap kesulitan belajar biokimia telah dilakukan oleh Halmo et al., (2018) mengungkapkan bahwa kesulitan belajar pada biokimia dapat terjadi pada materi asam amino dan mekanisme interaksi nonkovalen. Widyaningrum \& Wijayanti (2019) mengemukakan bahwa mahasiswa belum mampu melaksanakan praktikum biokimia secara sistematis, dimana seharusnya dalam matakuliah biokimia dan praktikum mahasiswa harus dilatih kemampuan kerja ilmiahnya melalui praktikum. Rahmatan (2016) menganalisis aspek materi biokimia yang sulit untuk dipahami mahasiswa. Dikemukakan bahwa konsep yang sulit dipahami adalah tentang metabolisme karbohidrat yang mengandung konsep abstrak dan konsep yang menyatakan proses, sehingga untuk membantu mahasiswa mempelajarinya dikembangkan pembelajaran biokimia berbasis computer dengan model drill and practice yang dikemas dalam software yang dapat mengukur penguasaan konsep dan keterampilan berpikir kreatif mahasiswa. 
Alasan banyak mahasiswa mengalami kesulitan belajar biokimia adalah materi biokimia padat tetapi waktu perkuliahan terbatas dan mahasiswa lebih menyukai media elektronik dalam mempelajari materi (Munawaroh et al., 2019), karakteristik materi dan bahan ajar yang terbatas (Wahyuni, 2019), banyak konsep yang harus dipelajari, konsep yang tidak relevan dengan kehidupan mahasiswa serta untuk memahami konsep biokimia diperlukan keterampilan berpikir tingkat tinggi (Usman, 2019). Biokimia merupakan mata kuliah yang dianggap sulit juga diungkapkan oleh Lismaya (2017), Bukhari et al., (2019), dan Usman (2019). Bahkan Perumcheril (2017) mengungkapkan biokimia adalah pelajaran yang membosankan.

Berdasarkan pemaparan tentang penelitian sebelumnya, maka perlu dilakukan suatu tindakan analisis terhadap kesulitan belajar biokimia pada mahasiswa Program Studi Pendidikan Biologi FKIP Universitas Mulawarman. Penelitian ini perlu dilakukan sebagai bagian dari upaya evaluasi terhadap kesulitan belajar mata kuliah biokimia mahasiswa. Penelitian ini juga dapat berfungsi sebagai bahan need analysis mengatasi kesulitan belajar mahasiswa. Lebih jauh penelitian ini bertujuan mengungkapkan kesulitan-kesulitan belajar mahasiswa serta untuk membantu mahasiswa menemukan solusi dalam proses belajar dan pembelajaran mata kuliah biokimia terutama pada Program Studi Pendidikan Biologi FKIP Universitas Mulawarman. Berbagai upaya pembenahan proses belajar dan pembelajaran dari hasil evaluasi dan need analysis diharapkan dapat dilakukan dan direalisasikan sesuai dengan karakteristik mahasiswa, kondisi sarana dan pra sarana pembelajaran, sesuai dengan tuntutan kurikulum sebagai calon guru dan kebutuhan mahasiswa akan mata kuliah biokimia sebagai bekal dasar untuk mempelajari mata kuliah selanjutnya.

\section{METODE}

Penelitian ini merupakan penelitian deskriptif dengan metode survei. Populasi pada penelitian ini adalah mahasiswa Program Studi Pendidikan Biologi FKIP Universitas Mulawarman yang telah menempuh mata kuliah biokimia. Partisipan pada penelitian ini adalah sejumlah 38 orang mahasiswa angkatan 2018/2019 yang menempuh MK Biokimia dan dipilih berdasarkan teknik purposive sampling. Penelitian dilakukan pada Bulan Desember 2019 di Gedung Kuliah C FKIP Universitas Mulawarman.

Data dikumpulkan menggunakan instrumen berupa kuesioner. Kuesioner memuat pertanyaan terbuka dengan indikator (1) sumber belajar mahasiswa; (2) cara belajar mahasiswa; (3)bentuk pembelajaran yang diharapkan oleh mahasiswa, dan (4) kesulitan mahasiswa dalam mempelajari materi biokimia. Setiap indikator memuat satu butir pertanyaan. Data yang telah diperoleh dianalisis secara kualitatif menggunakan teknik persentase. 


\section{HASIL DAN PEMBAHASAN}

Penelitian dilakukan dengan menyebarkan angket kuesioner dengan pertanyaan yang dapat dijawab secara terbuka oleh mahasiswa. Hasil analisis kuesioner dapat dilihat pada tabel dan diagram berikut.

Tabel 1. Hasil Analisis terhadap Kesulitan Materi Perkuliahan Biokimia

\begin{tabular}{clc}
\hline No. & Materi & Persentase (\%) \\
\hline 1. & Struktur Molekul & 36 \\
2. & Jalur-jalur Metabolisme & 42 \\
3. & Istilah-istilah dalam Biokimia & 22 \\
\hline
\end{tabular}

Berdasarkan data hasil analisis pada Tabel 1 dapat diketahui bahwa secara umum terdapat tiga kategori kesulitan mahasiswa terkait dengan materi biokimia, yaitu tentang struktur molekul, jalur metabolisme dan istilah-istilah dalam biokimia. Kesulitan tertinggi ialah pada materi jalurjalur metabolisme, yaitu sebanyak $42 \%$.

Tabel 2. Hasil Analisis terhadap Cara Belajar Materi Biokimia

\begin{tabular}{clc}
\hline No. & Cara Belajar & Persentase (\%) \\
\hline 1. & Diskusi & 27 \\
2. & Penjelasan Dosen & 33 \\
3. & Mempelajari Video & 16 \\
4. & Mempelajari Gambar & 14 \\
5. & Praktikum & 6 \\
6. & Penugasan & 4 \\
\hline
\end{tabular}

Berdasarkan data hasil analisis pada Tabel 2 dapat diketahui bahwa mahasiswa masih cenderung menyukai penjelasan dari dosen dalam mempelajari materi biokimia dengan menempati persentase hasil analisis sebanyak 33\%. Sebanyak 27\% mahasiswa menyenangi cara belajar dengan melakukan diskusi. Sisanya mahasiswa menyenangi cara belajar dengan menggunakan video animasi, gambar ataupun bagan-bagan, melalui kegiatan praktikum dan penugasan.

Tabel 3. Hasil Analisis terhadap Sumber Belajar Mahasiswa dalam Mempelajari Biokimia

\begin{tabular}{clc}
\hline No. & Sumber Belajar & Persentase (\%) \\
\hline 1. & Data dari internet (artikel, gambar, video, dst.) & 36 \\
2. & Buku & 28 \\
3. & Diskusi dengan Dosen dan Sejawat & 36 \\
\hline
\end{tabular}

Berdasarkan data hasil analisis pada Tabel 3 dapat diketahui bahwa sumber belajar mahasiswa dalam pembelajaran biokimia adalah informasi dan data dari internet baik dari artikel, gambar, video dan lain sebagainya, buku dan diskusi dengan dosen dan sejawat. Buku yang 
digunakan mahasiswa berupa buku teks biokimia baik tercetak maupun buku elektronik. Diskusi dengan dosen dan teman sejawat dilakukan ketika di kelas pada kegiatan tatap muka.

Tabel 4. Hasil Analisis terhadap Cara Belajar Biokimia yang Diharapkan Mahasiswa

\begin{tabular}{clc}
\hline No. & Bentuk Pembelajaran & Persentase (\%) \\
\hline 1. & Berbantuan video & 50 \\
2. & Berbantuan tayangan presentasi & 18 \\
3. & Berbantuan bahan ajar seperti buku yang mudah dipahami & 32 \\
\hline
\end{tabular}

Berdasarkan data hasil analisis pada Tabel 4 terungkap bahwa 50\% responden mengharapkan pembelajaran berbantuan video. Sebanyak $18 \%$ responden mengharapkan pembelajaran dengan berbantuan tayangan presentasi dan 32\% mengharapkan pembelajaran yang berbantuan bahan ajar seperti buku yang mudah untuk dipahami.

Kesulitan belajar pada mahasiswa terkait materi biokimia sebagaimana terdapat pada Tabel 1. merupakan fenomena yang tidak hanya terjadi pada mahasiswa Program Studi Pendidikan Biologi FKIP Universitas Mulawarman, namun juga pada mahasiswa pada institusi lain sebagaimana diungkap oleh Bukhari, Muhammad, \& Nasruddin (2019); Munawaroh et al., (2019); Usman (2019), Wodyaningrum \& Wijayanti (2019); Halmo et al., (2018); Lismaya (2017); dan Rahmatan (2016). Kesulitan belajar mahasiswa Prodi Pendidikan Biologi FKIP Universitas Mulawarman meliputi struktur molekul, jalur-jalur metabolisme dan istilah-istilah dalam biokimia. Ketiga kategori materi tersebut secara umum dikarenakan biokimia memiliki cakupan pengetahuan yang luas, namun biasanya memiliki waktu untuk belajar yang singkat (Munawaroh et al., 2019).

Struktur molekul biasanya tersaji dalam bentuk diagram. Begitu pula jalur metabolisme yang biasanya tersaji dalam bentuk diagram alir. Hal ini sebagaimana pernyataan Lowe (1993) bahwa diagram biasanya digunakan untuk menggambarkan informasi materi yang kompleks dan abstrak. Kesulitan terkait materi ini dikarenakan adanya kesulitan dalam membaca dan menafsirkan diagram maupun skema ilustrasi molekul (Schönborn, Anderson, \& Grayson, 2001). Diagram biasanya diartikan pada tingkat permukaan saja tanpa memahami lebih lanjut makna dari diagram yang tersaji dalam sumber belajar biokimia. Keterampilan dalam menafsirkan diagram merupakan keterampilan yang didapat oleh mahasiswa melalui serangkaian pengalaman belajar dan erat kaitannya dengan prior knowledge mahasiswa (Lowe, 1993). Lebih lanjut, kesalahan dalam membaca dan menafsirkan diagram struktur molekul yang merupakan dasar dari biokimia dapat menyebabkan terjadinya miskonsepsi pada materi biokimia dan tidak dapat memahami materi biokimia yang lebih rumit dan kompleks, misalnya reaksi perubahan gugus molekul dan metabolisme. 
Kesulitan dalam memahami jalur metabolisme, selain karena kurang mampu dalam membaca diagram juga dikarenakan materi tersebut merupakan materi yang detail (Wood, 1990). Penyajian materi jalur metabolisme pada sumber belajar pada umumnya dalam bentuk diagram alir yang disertai dengan struktur molekul, rumus kimia, nama molekul, panah yang menggambarkan arah reaksi, yang disertai dengan enzim yang mengatalisis setiap perubahan. Materi yang mendetail pada jalur metabolisme memunculkan permasalahan, yaitu harus dipahami ataukah menghafalkan setiap langkah-langkahnya. Hal ini membuat permasalahan kesulitan belajar mahasiswa dalam memahami materi biokimia semakin bertambah.

Pada materi biokimia, terdapat banyak istilah-istilah yang digunakan. Adanya perubahan struktur, maka berubah pula istilah yang digunakan, begitu pula notasinya. Misalnya saja istilah yang sering digunakan yaitu glukosa. Pada pembahasannya dalam pembelajaran biokimia glukosa bukan sekedar gula, namun lebih lanjut glukosa merupakan gula sederhana yang termasuk golongan monosakarida. Glukosa memiliki rumus kimia $\mathrm{C}_{6} \mathrm{H}_{12} \mathrm{O}_{6}$. Kesulitan lain dalam memahami istilah pada materi biokimia adalah adanya istilah lain yang harus dipahami dan diketahui. Misalnya saja dicontohkan oleh Wood (1990) satu istilah, yaitu galaktosemia. Agar dapat memahami galaktosemia, maka mahasiswa harus dapat mengetahui tentang gula, ikatan glikosida, asam amino, protein, enzim, struktur hierarkis dari jalur metabolisme yang menyangkut istilah tersebut. Kesulitan dalam mengenal dan memahami istilah dapat semakin menyulitkan mahasiswa dalam mempelajari materi biokimia.

Kesulitan belajar secara umum dapat dipengaruhi oleh faktor internal dan eksternal (Cahyono, 2019; Utami, 2019; Sahade \& Rijal, 2018; Nofitasari \& Sihombing, 2017). Kesulitan dalam mempelajari biokimia dapat dipengaruhi juga oleh beberapa faktor internal dan eksternal. Faktor internal diantaranya kondisi mahasiswa, minat dan motivasi belajar mahasiswa, cara belajar mahasiswa, misalnya lebih menyukai belajar dengan menggunakan media elektronik (Munawaroh et al., 2019), kurang dapat memahami materi yang disampaikan guru dan tidak mencatat materi yang dipelajari, serta jarang mengerjakan tugas tepat waktu (Sahade \& Rijal, 2018). Faktor Eksternal yang mempengaruhi diantaranya adalah karakteristik materi biokimia itu sendiri (Usman, 2019; Wahyuni, 2019), faktor pedagogis yang dapat terdiri atas bahan ajar dan metode mengajar (Utami, 2019). Biokimia memuat materi yang luas dan kompleks yang biasanya dipelajari dalam waktu yang singkat. Pada materi biokimia yang dipelajari Prodi Pendidikan Biologi FKIP Universitas Mulawarman terdapat kemungkinan adanya kurangnya kesesuaian materi yang diperlukan mahasiswa sebagai calon guru. Sebagaimana dinyatakan oleh Usman (2019) bahwa terdapat penyampaian materi biokimia yang tidak relevan dengan kehidupan mahasiswa. Terdapat indikasi bahwa materi biokimia yang disampaikan kurang relevan dengan apa yang diperlukan mahasiswa sebagai bekal calon guru maupun dengan peristiwa yang kontekstual yang terkait dengan pengalaman diri mahasiswa sehari-hari. 
Faktor lain yang juga dapat mempengaruhi adanya kesulitan belajar biokimia diantaranya adalah faktor pedagogis. Faktor pedagogis misalnya adalah keterbatasan metode yang digunakan dalam pembelajaran (Susilo, 2017). Berdasarkan hasil analisis, penjelasan dosen dan diskusi baik dengan dosen maupun teman sejawat masih merupakan pilihan utama mahasiswa. Hal ini mencerminkan bahwa sumber belajar yang ada, baik buku, video, gambar dan media lainnya masih belum mampu dimanfaatkan secara maksimal oleh mahasiswa dalam membangun pengetahuan.

Diagnosis kesulitan belajar mahasiswa berimplikasi terhadap adanya upaya untuk meminimalisir serta mengatasi permasalahan kesulitan belajar mahasiswa pada pembelajaran biokimia. Upaya ke depan yang dapat dilakukan berdasarkan data pada Tabel 4 adalah melakukan berbagai pengembangan terkait dengan media pembelajaran seperti video, tayangan pembelajaran yang dilengkapi dengan gambar dan animasinya sehingga dapat membuat mahasiswa lebih fokus dan terarah dalam memahami materi, memperbaiki proses pembelajaran, dapat pula mengembangkan bahan ajar yang mudah dipahami bahasanya dan memiliki keruntutan materi yang disesuaikan dengan keperluan mahasiswa dalam mempelajari materi biokimia.. Hasil ini sejalan dengan penelitian Munawaroh et al., (2019) dan Seruni et al., (2019) yang menunjukkan bahwa mahasiswa menginginkan bahan ajar lain selain buku teks dan ingin belajar melalui video, oleh karenanya dikembangkanlah e-Module. Bukhari, Muhammad, \& Nasruddin (2019) mengembangkan suatu bahan ajar untuk mengatasi kesulitan belajar mahasiswa dan Uliyandari (2018) yang mengembangkan modul untuk meningkatkan hasil belajar dan respon mahasiswa pada pembelajaran biokimia. Pada kegiatan praktikum pembelajaran biokimia juga dapat dikembangkan petunjuk praktikum (Widyaningrum dan Wijayanti, 2019; Wijayanti \& Lestari, 2016), serta instrumen penilaian praktikum (Puspitasari, 2018). Penelitian ini juga dapat dijadikan dasar sebagai tindakan perbaikan dalam proses pembelajaran utamanya pada strategi dan metode pembelajaran. Upaya yang dilakukan oleh Usman (2019) untuk mengatasi permasalahan dalam pembelajaran biokimia adalah dengan menerapkan pembelajaran yang mengembangkan keterampilan berpikir kritis melalui pembelajaran berbasis masalah. Pembelajaran biokimia berbasis student centered learning dengan metode pecahan juga dapat membantu mahasiswa untuk mudah menguasai dan memahami pembelajaran biokimia (Lismaya, 2017).

Lebih lanjut, berdasarkan hasil analisis yang dilakukan juga diperlukan pengembangan bahan ajar biokimia yang 1) kontennya disesuaikan dengan keperluan calon guru, yaitu memuat materi yang sesuai dengan KI dan KD IPA di SMP dan Biologi di SMA; 2) bahasanya sederhana sehingga mudah dipahami oleh pembelajar dalam hal ini mahasiswa; 3) penyajiannya runtut, sehingga dapat membantu mahasiswa untuk menata alur berpikirnya dalam mempelajari biokimia. Bahan ajar yang dikembangkan hendaknya juga memuat keterkaitan antara materi biokimia dengan kehidupan sehari-hari sehingga pengetahuan mahasiswa dapat terkait langsung 
dengan realita. Dengan demikian diharapkan bahan ajar yang dikembangkan dapat mendorong mahasiswa untuk dapat belajar bermakna dan dapat memahami materi biokimia dengan baik untuk digunakan sendiri ketika kuliah juga dapat diimplementasikan ketika mengajar nantinya di sekolah.

\section{SIMPULAN}

Berdasarkan pemaparan hasil dan pembahasan dapat disimpulkan bahwa kesulitan belajar mahasiswa terkait dengan materi biokimia, yaitu tentang struktur molekul, jalur metabolisme dan istilah-istilah dalam biokimia, secara umum cara belajar biokimia yang disenangi oleh mahasiswa ialah melalui penjelasan dosen dan kegiatan diskusi, sumber belajar yang digunakan oleh mahasiswa dalam mempelajari materi biokimia secara umum ialah menggunakan data dari internet, penjelasan dosen dan buku biokimia.

Penelitian lanjutan yang dapat dilakukan ialah dengan mengembangkan berbagai bahan ajar yang dapat membantu mahasiswa untuk belajar yang dapat berupa video pembelajaran, buku ajar yang mudah dipahami, modul, petunjuk praktikum serta bahan tayang yang menarik dan mudah dipahami.

\section{REFERENSI}

Bukhari, Muhammad, \& Nasruddin. (2019). Proses pengajaran biokimia di SMA berbasis bahan ajar yang terdapat dalam kehidupan sehari-hari. Jurnal Dedikasi Pendidikan, 8848(2), 87-90.

Butnariu, M., Petrescu, I., \& Ioan, S. (2018). Interdisciplinary character of biochemistry. Jacob Journal of Biochemistry, 3(1), 1-5.

Cahyono, H. (2019). Faktor-faktor kesulitan belajar siswa MIN Janti. Jurnal Dimensi Pendidikan Dan Pembelajaran, 7(1), 1. https://doi.org/10.24269/dpp.v7i1.1636

Halmo, S. M., Sensibaugh, C. A., Bhatia, K. S., Howell, A., Ferryanto, E. P., Choe, B., Kehoe, K., Watson, M., \& Lemons, P. P. (2018). Student difficulties during structure-function problem solving. Biochemistry and Molecular Biology Education, 46(5), 453-463. https://doi.org/10.1002/bmb.21166

Ismail. (2016). Diagnosis kesulitan belajar siswa dalam pembelajaran aktif di sekolah. Jurnal Edukasi, 2(1), 30-43.

Lismaya, L. (2017). Penerapan pembelajaran biokimia berbasis student center learning (SCL) terhadap kemampuan pemecahan masalah mahasiswa. Bioeduin: Jurnal Program Studi Pendidikan Biologi, 7 (1).

Lowe, R. K. (1993). Diagrammatic information: Techniques for exploring its mental representation and processing. Information Design Journal, 7(1),3-17. https://doi.org/10.1075/idj.7.1.01low

Munawaoh, S., Seruni, R., Nurjayadi, M., \& Kurniadewi, F. (2019). Pengembangan modul elektronik (E-Module) biokimia pada materi metabolisme karbohidrat menggunakan flip pdf $\begin{array}{lllll}\text { professional. Jurnal Tadris Kimiya, 4(1), 69-77. } & \text { DOI: }\end{array}$ http://dx.doi.org/10.15575/jtk.v4i1.4679 
Nofitasari, I., \& Sihombing, Y. (2017). Deskripsi Kesulitan Belajar Peserta Didik Dan Faktor Penyebabnya Dalam Memahami Materi Listrik Dinamis Kelas X Sma Negeri 2 Bengkayang. $\begin{array}{llllll}\text { Jurnal Penelitian Fisika Dan Aplikasinya (JPFA), } & \text { 7(1), } 44 .\end{array}$ https://doi.org/10.26740/jpfa.v7n1.p44-53

Perumcheril, R. J. (2017). Self-assessment and review of biochemistry, Second edition. New Delhi: Jaypee Brothers Medical Publishers.

Puspitasari, E. D. (2018). Analisis Keterbacaan Instrumen Penilaian Psikomotorik pada Praktikum Biokimia Mahasiswa Pendidikan Biologi. Proceeding Biology Education Conference, 15, 583-586.

Rahmatan, H. (2016). Biochemistry concept level of difficulty profile of prospective biology teachers' perception. Proceedings of the 6th Annuual International Conference Syiah Kuala University (AIC Unsyiah) in Conjunction with the 12th International Conference on Mathematics, Statistics and Its Application (ICMSA) 2016, 363-366.

Rizki, M., Nugraha, R. E. M., \& Saleh, R. (2017). Faktor-faktor penyebab Kesulitan Belajar Peserta Didik Pada Mata Pelajaran Menggambar Teknik Pada Siswa (Studi kasus siswa kelas X TGB SMK N 1 Jakarta) pada tahun 2016. Jurnal PenSil Jurusan Teknik Sipil FT UNJ, 9(1), 1-9.

Rodwell, V., Bender, D., Botham, K., Kennely, P., Weil, P.A. (2018). Harper's Illustrated Biochemistry, Thirty-First Edition. New York: McGraw-Hill Education.

Sahade, S., \& Rijal, A. (2018). Faktor-faktor yang mempengaruhi kesulitan belajar peserta didik pada mata pelajaran akuntansi perusahaan jasa di SMK Negeri I Bungoro Kabupaten Pangkep. JEKPEND: Jurnal Ekonomi Dan Pendidikan, 1(1), 01. https://doi.org/10.26858/jekpend.v1i1.5047

Schönborn, K. J., Anderson, T. R., \& Grayson, Di. J. (2001). Biochemistry Students' Difficulties with the Interpretation of Textbook Diagrams. Proceedings of the 9th Annual Meeting of the Southern African Association for Research in Mathematics, Science and Technology Education (SAARMSTE), 2, 53-61.

Seruni, R., Munawaoh, S., Kurniadewi, F., \& Nurjayadi, M. (2019). Pengembangan modul elektronik (E-Module) biokimia pada materi metabolisme lipid menggunakan flip pdf professional. Jurnal Tadris Kimiya, 4(1), 48-56. https://doi.org/10.15575/jtk.v4i1.4672

Susilo, B. E. (2017). Analisis kesulitan belajar mahasiswa pada materi hal sejajar, bersilangan, dan tegak Lurus Dalam Mata Kuliah Geometri ruang ditinjau dari gaya belajar mahasiswa. SOSIOHUMANIORA: Jurnal Ilmiah Ilmu Sosial Dan Humaniora, 3(2), 127-136. https://doi.org/10.30738/sosio.v3i2.1611

Uliyandari, M., Sumpono, S., \& Susanta, A. (2019). Implementasi modul analisis konsentrasi protein terhadap hasil belajar dan respon mahasiswa pada pembelajaran biokimia II. PENDIPA Journal of Science Education, 3(3), 120-124. https://doi.org/10.33369/pendipa.3.3.120-124

Usman. (2019). Analisis Persepsi Mahasiswa Terhadap Pembelajaran Biokimia Yang Mengembangkan Keterampilan Berpikir Kritis. Prosiding Seminar Nasional Pendidikan FKIP, 2(1), 106-112.

Utami, A. P. (2019). Kesulitan belajar kesulitan belajar: gangguan psikologi pada siswa dalam menerima pelajaran. ScienceEdu, $I I(2), 92-96$.

Voet, D., Voet, J. G., \& Pratt, C. W. (2016). Fundamentals of Biochemistry: Life at the Molecular Level, Fifth Edition. United States of America: Wiley.

Wahyuni, T. S. (2019). Pengembangan buku ajar matakuliah biokimia berintegrasi dengan nilainilai sains dalam Alquran. Jurnal Zarah, 7(1), 1-6. 
https://doi.org/10.31629/zarah.v7i1.1259

Widyaningrum, D. A., \& Wijayanti, T. (2019). Implementasi buku petunjuk praktikum biokimia berbasis inkuiri terbimbing untuk meningkatkan kemampuan kerja ilmiah. Edubiotik: Jurnal Pendidikan, Biologi Dan Terapan, 4(02), 58-67. https://doi.org/10.33503/ebio.v4i02.437

Wijayanti, T., \& Lestari, P. B. (2018). Modifikasi materi praktikum (karbohidrat-enzim) untuk meningkatkan pemahaman konsep biokimia secara komprehensif dan efisien. Paradigma: Jurnal Filsafat, Sains, Teknologi, Dan Sosial Budaya, 23(2), 95-100. https://doi.org/10.33503/paradigma.v23i2.406

Wood, E. J. (1990). Biochemistry is a difficult subject for both student and teacher. Biochemical Education, 18(4), 170-172.

Żymańczyk-duda, E., Brzezińska-rodak, M., \& Klimek-ochab, M. (2016). Biochemistry knowledge to practical applications - examples. Basic Biochemistry, December 2017, 1-36. 